\title{
DEPLOYING AMBIDEXTERITY THROUGH BETTER MANAGEMENT PRACTICES: AN INVESTIGATION BASED ON HIGH-VARIETY, LOW-VOLUME MANUFACTURING
}

\author{
Mile Katic and Dilek Cetindamar \\ Faculty of Engineering and IT, University of Technology Sydney, \\ Sydney, Australia, and \\ Renu Agarwal \\ UTS Business School, University of Technology Sydney, Sydney, Australia
}

\begin{abstract}
Purpose:

While capabilities in exploiting existing assets and simultaneously exploring new growth opportunities have proven essential components in competition, an understanding of how organisations deploy these so-called ambidextrous capabilities remains elusive. Thus, we aim to investigate the role of better management practices (BMP), as organisational routines, in deploying ambidextrous capabilities in practice.
\end{abstract}

Design/methodology/approach:

High-Variety, Low-Volume (HVLV) manufacturers are adopted as exemplar ambidextrous organisations. A conceptual model was developed where BMP, by way of human resource management (HRM) and production planning and control (PPC), are considered mediators in the relationship between ambidextrous capabilities and organisational performance outcomes. Partial least squares structural equation modelling was adopted to analyse the survey undertaken in Australia.

Findings:

The results suggest that merely holding ambidextrous capabilities is not enough - demonstrating a fully mediating role of BMP between ambidextrous capabilities and HVLV manufacturer performance outcomes. However, the individual effects of PPC and HRM prove varied in their unique impact on HVLV manufacturer performance.

Originality:

By exemplifying the explanatory power of BMP in ambidextrous capability deployment, this study moves beyond the more prevalent stance on the links between BMP and ambidextrous capabilities as that of capability building through management practices, to one concerning the deployment of the capability itself.

Practical implications:

This study also provides a rare account of how HVLV manufacturers can leverage their inherently ambidextrous design towards greater organisational performance and demonstrate critical considerations in selecting organisational capabilities.

Key Words: Ambidexterity, Better Management Practices, High-Variety, Low-Volume Manufacturing 


\section{Introduction}

Organisations' ability to exploit existing resources towards efficiency improvements has become an increasingly pervasive area of concern for operations scholars and practitioners (Andriopoulos et al. 2018). While extant literature suggests that organisations holding these so-called ambidextrous capabilities observe greater organisational performance (Junni et al. 2013), the question of how this happens remains a strongly contested (Wu et al. 2020, Felício et al. 2019) and ambiguous (Andriopoulos et al. 2018, Benner and Tushman 2015) phenomenon.

We aim to key into this conversation by conceptualising ambidexterity as a dynamic capability (DC) (D'Souza et al. 2017, O'Reilly and Tushman 2008). Taking cues from DC theory (Eisenhardt and Martin 2000, Winter 2003), we build on this understanding of ambidextrous capabilities and introduce the notion of better management practices (BMP) as a potential conduit from which ambidextrous capabilities can impact organisational performance outcomes.

In adopting the case of high-variety, low-volume (HVLV) manufacturers as exemplar ambidextrous organisations, our survey data suggests that merely holding ambidextrous capabilities is not enough. Instead, we find that BMP - consisting of production planning and control (PPC) and human resource management (HRM) practices - fully mediate the relationship between ambidextrous capabilities and organisational performance outcomes. We follow the call for more research into the role of management practices in leveraging ambidextrous capabilities in practice ( $\mathrm{Wu}$ et al. 2020, Birkinshaw and Gupta 2013) and the relationship between ambidextrous capabilities and lowerorder routines (Zimmermann and Birkinshaw 2016). We provide evidence to support the changing role of lower order routines in supporting DC in impacting organisational performance outcomes (Schriber and Löwstedt 2020, Waleczek et al. 2019, Protogerou et al. 2011). By considering BMP as a mediating factor, we also flip the discussion from how ambidextrous capabilities can help facilitate the link between BMP and organisational performance outcomes to one concerning the deployment of the capability itself. In doing so, we find that while organisations can certainly build ambidextrous capabilities, it does not necessarily equate to better performance outcomes.

The paper has five sections. Section 2 provides an overview of the theoretical basis leading to our conceptual model in the context of HVLV manufacturing. Section 3 articulates the research methodology, while Section 4 illustrates the results of this research. Finally, Section 5 provides a discussion and conclusion involving implications to both theory and practice and outlining the limitations and potential areas for further research. 


\section{Ambidexterity, Better Management Practices, and HVLV}

\section{Manufacturer Performance}

\subsection{Ambidexterity as a Dynamic Capability: The Role of Management Practices}

In general, an organisations' capacity to realise benefits from the seemingly contradictory tensions of exploration and exploitation appears driven by their ability to formulate a viable strategic trajectory (c.f. Pisano 2017). Thus, ambidexterity is not necessarily a source of competitive advantage in itself; it is the resource reconfigurations stemming from this capability that seems to facilitate this (O'Reilly and Tushman 2008).

Such a conceptualisation holds important implications for the understanding of how ambidexterity is achieved in practice. Keeping with the understanding of capabilities as "high-level routine[s]... that, together with its implementing input flows, confers upon an organization's management a set of decision options for producing significant outputs of a particular type" (Winter 2003, p. 991), we would assume 1) ambidextrous capabilities exist on a higher-level than routines (i.e., is formed by lower-level routines); 2) routines are not the only "inputs" - competencies also draw on skill, knowledge and governance mechanisms (Teece 2007) and;3) ambidexterity is a managerial construct involving actual decision-making and is hence not purely a function of environment or context (Birkinshaw and Gupta 2013). Thus, ambidextrous capabilities can be characterised as a function of "lower-level" routines that, together with other "inputs," including structure and governance mechanisms, enable an organisation to explore and exploit through effective leadership. What this also suggests, however, is that holding ambidextrous capabilities and deploying them may be two different phenomena (Wilden et al. 2016).

Simultaneously leveraging exploitation and exploration is no easy feat. Both activities require fundamentally different structures, processes, and cultures to function ( $O^{\prime}$ Reilly and Tushman 2008). These activities often become self-reinforcing as well (March 1991). The same goes for organisations competing based on both exploration and exploitation simultaneously, i.e., when significant strategic direction changes occur. Thus, a change is necessary to this balance; the organisation stagnates (Luger et al. 2018). Indeed, there are marked differences in firms' performance that can leverage ambidexterity (Birkinshaw and Gupta 2013, Junni et al. 2013, O'Reilly and Tushman 2013, Pisano 2017, Wu et al. 2020).

The fact that operational processes impact ambidextrous capability deployment is not an entirely new development. Operations scholars have grappled with this problem in the guise of the productivity dilemma for some time, have long warned about the interactions between operational 
routines and their impact on exploitation and exploration (Adler et al. 2009, Benner and Tushman 2003). More recent work has also begun to investigate this impact, bringing forth a nuanced understanding of this relationship (Matthews et al. 2015). Tamayo-Torres et al. (2017) argued that ambidextrous capabilities could help facilitate manufacturing improvements in quality, delivery, cost, and flexibility via the sand cone model. This work suggests that ambidextrous capabilities may be conducive to the simultaneous adoption of seemingly incompatible management practices.

The theoretical support for these arguments also appears to stem from similarities between process improvement initiatives and DC, citing that they may be the same (Anand et al. 2009, Eisenhardt and Martin 2000). In this case, leveraging DC involves explicit attention towards creating a sufficient foundation that includes standardised management practices. Which practices are adopted, and how they are adopted involves a skill level that shows how an organisation can leverage its capabilities to any practical effect (Teece 2017). Complementarities between management practices also play a crucial role in leveraging conflicting organisational demands in exploitation and exploration (MacDuffie 1995). These management practices once characterised as ordinary, zeroorder, or operational capabilities (Helfat and Winter 2011) have emerged as just as necessary in achieving competitive parity by continuous organisational adaptation in exploratory and exploitative goals as higher order DC (Schriber and Löwstedt 2020).

Despite these significant attempts to realise the role of management practices in making ambidextrous capabilities work, there remains ambiguity in uncovering how their interactions influence organisational performance outcomes. Despite this question being raised by Anand et al. (2009) in the role of management practices in helping to make use of ambidextrous capabilities, also partially addressed by Matthews et al. (2015), the organisational outcomes of their interactions, particularly the deployment of the capability through routines (Zimmermann and Birkinshaw 2016), leave much to be desired. 


\subsection{The Case of HVLV Manufacturing and Better Management Practices}

HVLV manufacturers are typically characterised as small to medium sized enterprises (SME's) that produce a high variety of products at low volumes (Katic and Agarwal 2018). In terms of manufacturing strategy, they can present themselves as both make-to-order or engineer-to-order organisations, depending on where the customer order infiltrates the manufacturing value chain (Katic and Agarwal 2018).

The project-based nature of their manufacturing strategy means uncertainty impacts operations from both the external environment (from the types of products produced) as well as internal to the firm (from the manufacture of the goods themselves) (Stevenson et al. 2005). Intuitively, a core competency in HVLV manufacturing is in effectively navigating through the variations in customer demand and product specifications towards completing the job within time and budget goals (Adrodegari et al. 2015). Thus, it is not uncommon to see the job-shop style of production being adopted with flexibility in processes, machinery, and personnel proving essential to retaining a viable organisation and meeting the requirements of requisite variety (Amaro et al. 1999). However, to operate faster, better, and cheaper than their competitors, the HVLV manufacturer must be able to break-free from operational norms towards leveraging their internal capabilities to meet disparate customer needs (Katic and Agarwal 2018). That is to say; the HVLV manufacturer must be able to harness the knowledge and skill encapsulated in operational routines towards improving their ability to undertake project-based work and simultaneously be responsive to changing customer requirements. HVLV manufacturers need to be ambidextrous if they survive in the longterm, making such firms an exemplar case for this study's purposes.

On the other hand, BMP presents themselves as routinised patterns of behaviour that appear better than others in achieving greater organisational performance outcomes. Stemming from the bestpractice tradition in manufacturing strategy literature (Voss 1995), BMP has (re)emerged as a significant factor explaining major differences in productivity between firms (Agarwal et al. 2014) as well as entire economies (Bloom and Van Reenen 2006). Some researchers establish a competitive advantage theory based on the BMP concept (Bromiley and Rau 2014).

The logic behind BMP closely resembles best-practice research in operations management to select exemplar practices across multiple contexts (Voss 1995). The fact they appear as observable and measurable artefacts (Bloom and Van Reenen 2006) has not only aided in their popularity amongst scholars, but it also seems to portray qualities that can then be easily transferred amongst different organisations. However, the BMP adoption is, in itself, a skill that requires substantial effort upon implementation (Bloom et al. 2018). 
We pursue the notion of BMP in this study because of their perceived role as one of the building blocks for DC (Teece 2017). BMP characterise "stability" and exploitative tendencies in organisations (Benner and Tushman 2003), as well as they propel innovation and aid exploration (Agarwal et al. 2014),

\subsection{Ambidextrous Capabilities, Better Management Practices and HVLV}

\section{Manufacturer Performance}

Given the objective to investigate the role of routines (by virtue of BMP) in the link between ambidexterity and organisational performance outcomes, the research model in Figure 1 was developed.

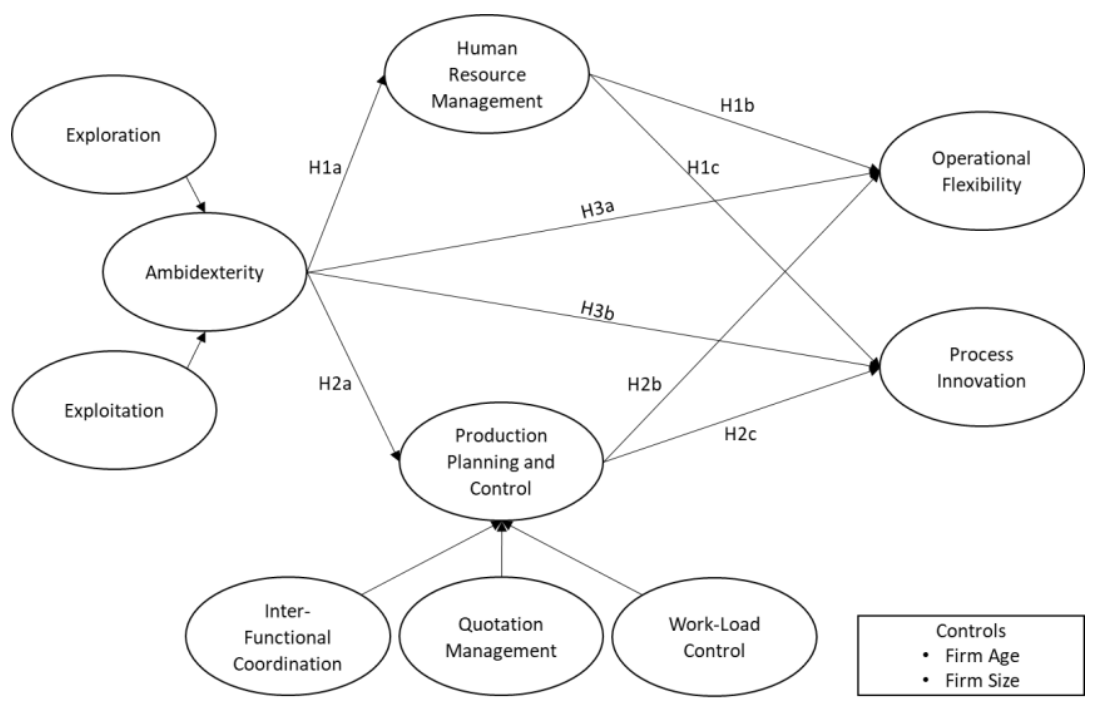

Figure 1 Research Model

Provided the HVLV manufacturing context, the dependant variables representing organisational performance outcomes are related to their core competencies in producing a wide variety of customised products (operational flexibility) and doing this well (process innovation). Human resource management and production planning and control were selected as BMP to reflect their underlying significance in HVLV manufacturing literature, particularly their prevalence in studies concerning best-practice in such a context (Petroni et al. 2017).

Firm age and firm size were selected as controls due to their known impacts on BMP adoption (Agarwal et al. 2014) in the case of the latter and the peculiarities associated with flexibility, legitimacy, and resource constraints (Carayannopoulos 2017) in the case of the former. 


\section{Human Resource Management Practices}

HRM is a known driver enabling ambidextrous capabilities (Úbeda-García et al. 2018). In this case, however, we are not necessarily concerned with fostering or building ambidextrous capabilities, rather in deploying these capabilities themselves. Thus, it is essential to recognise ambidextrous firms also require "ambidextrous" people (Miron-Spektor et al. 2017). In this respect, HRM practices, including employee training and job-security, are said to improve an employees' ability, motivation, and opportunity to perform (Jiang et al. 2012). Ambidexterity has also been associated with the complimentary adoption of both performance management practices and those which create an adequate social context (Birkinshaw and Gibson 2004) - also forming a key part of BMP literature in general (Bloom and Van Reenen 2006). Knowing individual motivation, know-how, skill, experience, and attitude are also drivers of translating capabilities into routines and routines into organisational outcomes (Abell et al. 2008 ); we construct the following hypotheses:

H1a: Ambidexterity is positively associated with the adoption of HRM practices

Along the same vein, workers in HVLV manufacturers are renowned for their flexibility in terms of dealing with the dynamism associated with the HVLV manufacturing strategy (Birkie et al. 2017). Traditionally speaking, they observe quite some pride in their ability to problem solve and ultimately "get the job done"(Clegg and Fitter 1981). HRM practices are an essential component in leveraging these talents towards world-class standards (Muda and Hendry 2003). Indeed, for the HVLV manufacturer, HRM practices present one of the more significant competitiveness areas in operational flexibility and process innovation performance (Petroni et al. 2017). Thus:

H1b: HRM practices are positively associated with HVLV manufacturer operational flexibility

H1c: HRM practices are positively associated with HVLV manufacturer process innovation performance

\section{Production Planning and Control Management Practices}

Effective production planning and control (PPC) has long been of concern for ambidextrous organisations such as HVLV manufacturers (Aslan et al. 2015, Stevenson et al. 2005). The use of PPC has been associated with greater performance by setting appropriate costs and lead-times towards increased competitiveness and navigating the uncertain environment in which they typically reside (Zennaro et al. 2019). Greater flexibility to deal with the influx of disparate orders presents itself as a by-product of effective PPC adoption (Katic and Agarwal 2018). Also, while more intuitive PPC 
approaches seem appropriate when business is slow when the order-book begins to rise, those HVLV manufacturers with effective PPC practices exhibit increased decentralisation levels and less myopic managerial decision making (Stevenson and Vanharanta 2015). This behavior has also been observed to help organisations leverage the contradictory demands of exploitation and exploration towards greater performance outcomes (Jansen et al. 2012). By taking on formal PPC practices, the top management team is "free" to perform more strategic and long-term decision-making. As Petroni et al. (2017) also assert, effective PPC is a form of innovation for HVLV manufacturers. Taking into consideration PPC forms a central component of both reactive flexibility and proactive flexibility, which effective HVLV manufacturers are suggested to hold (Katic and Agarwal 2018), we hypothesise the following:

H2a: Ambidexterity is positively associated with the adoption of PPC practices

H2b: PPC practices are positively associated with HVLV manufacturer operational flexibility

H2c: PPC practices are positively associated with HVLV manufacturer process innovation performance

The Mediating Role of Better Management Practices Between Ambidextrous Capabilities and HVLV Manufacturer Performance Outcomes

According to previous discussions, the inability to leverage ambidextrous capabilities towards organisational performance outcomes is a function of the relationship between organisational capabilities, routines, and performance outcomes. We suggest that ambidextrous capabilities are not enough to directly influence organisational performance as their capabilities rely on a synthesis between competing objectives by adopting routines (Helfat and Winter 2011). As per the capabilities-based view, it is the configurations of routines that drive performance outcomes, not necessarily their capabilities (Protogerou et al. 2011). Hence, we propose the following hypotheses:

H3a: PPC management practices mediate the relationship between ambidextrous capabilities and HVLV manufacturer performance outcomes.

$\mathrm{H} 3 \mathrm{~b}$ : HRM management practices mediate the relationship between ambidextrous capabilities and HVLV manufacturer performance outcomes. 


\section{Research Methodology}

\subsection{Development of Measures}

In developing the measures for constructs used in this research, we adopt the guidelines set-forth by Forza (2016) that involve articulating an operational definition of the construct, followed by assessing its content validity. Thus, the more established constructs of ambidexterity, process innovation, and operational flexibility were adapted to suit the study's objectives, while HRM and PPC management practices underwent a quantitative assessment of content validity using the content validity index (CVI).

The following outlines the development of each measure according to the type of content validity assessment undertaken.

\section{Ambidexterity}

Ambidexterity is defined as a DC, enabling the simultaneous pursuit of exploratory and exploitative activities. This DC becomes a maximising exercise where both exploration and exploitation's combinatory power results in greater organisational performance (Cao et al. 2009).

In taking the capabilities-based view of ambidexterity, and in line with D'Souza et al. (2017), we recognise that exploration and exploitation are two fundamentally distinct activities. Even though they are both required in achieving ambidexterity, they also impact organisational performance differently (Benner and Tushman 2015). Routines form exploratory and exploitative activities unique in their inputs, structure, and processes (O'Reilly and Tushman 2008). Thus, ambidexterity is a second-order reflective-formative construct consisting of exploratory and exploitative activities (Pertusa-Ortega and Molina-Azorín 2018). In our case, the measures for the first order reflective constructs of exploration and exploitation are adapted from a five-point Likert scale developed by Lubatkin et al. (2006).

Because content validity is a major concern for formative second-order constructs (Ringle et al. 2012), we conducted an expert workshop consisting of four academics with a keen understanding of organisational ambidexterity and HVLV manufacturing to assess this.

During the workshop, questions were raised over the efficacy of two measures relating to creating products and services and increasing automation in operations. It was concluded that HVLV manufacturing's nature renders new products/services limited in applicability. Along the same line, automation is of limited relevance in an HVLV manufacturing environment where predictive engineering techniques or pre-production activities are primarily applicable at higher levels of 
predictability (Haug et al. 2009). Given this, we removed these constructs from the survey. A final list of measures for the constructs of exploration and exploitation is shown in Appendix A.

\section{Operational Flexibility}

Operational flexibility refers to the ability of HVLV manufacturers to produce a wide range of products. It has a rich theoretical underpinning in manufacturing strategy literature (Netland and Frick 2017) and literature akin to HVLV manufacturers (Tamayo-Torres et al. 2017). Nonetheless, in this paper, we have opted to adopt the measures for operational (process) flexibility by Swink et al. (2005) given their relevance to the HVLV manufacturing environment.

\section{Process Innovation}

Process innovation means "new or significantly improved production or delivery methods [including] significant changes in techniques, equipment and software" (OECD and Communities 2005). As such, we adopt the measures for process innovation by Prajogo and Sohal (2003) that have focused on assessing the impact of management practices on organisational outcomes and their relevance for this study.

Quantitative Approach to Content Validity for Human Resource Management and Production Planning and Control

Since PPC and HRM (as BMP) have seen little empirical testing in the context of HVLV manufacturing, measures for these constructs were developed and tested before use in the final survey.

To accomplish this, we adopt the content validity index (Polit and Beck 2006, Forza 2016) whereby a group of experts assesses the degree to which a particular item helps explain the construct it is trying to measure (Polit and Beck 2006). A five-point Likert scale was used to evaluate their responses, ranging from not important (1) to very important (5). An "unsure" option was included in the instance where the subject matter expert was not familiar with a certain construct, in which case we could then remove this from the sample. In all, 13 subject matter experts participated, well above the minimum requirement of three (Lynn 1986).

Next, an evaluation of CVI requires two separate calculations at the individual item level (I-CVI) and at the entire scale level (S-CVI) (Lynn 1986). To calculate the I-CVI, we first code those responses that ranged from important (4) to very important (5) as an indicator of relevancy. Then, we calculate the I-CVI by dividing the number of subject matter experts that responded with a 4 or 5 by the total number of experts. To address the probability of chance occurrence $\left(P_{c}\right)$ inflating the CVI values, we adopt a modified Kappa statistic ( $K$ ) used by Zamanzadeh et al. (2015). The content validity at the 
scale level is then calculated, where S-CVI is found by averaging the item level CVI's (Polit and Beck 2006). The equations adopted for $P_{c}$ and $K$ are shown below, where $N$ is the number of subject matter experts in the panel, and A represents the number of subject matter experts that agree the item is important (thus, responding with a 4 or a 5 ).

$P_{c}=\left[\frac{N !}{A !(N-A) !}\right] * 0.5^{N}$

$K=\left(I C V I-P_{c}\right) /\left(1-P_{c}\right)$

Values of $\mathrm{K}$ above 0.74 can be considered excellent, while values between 0.6-0.74 can be considered acceptable, and values of 0.4-0.59 can be considered fair (Zamanzadeh et al. 2015).

\section{Production Planning and Control}

Initially, PPC consisted of two separate activities in sales and workload control. Because they are essential in explaining PPC overall and present themselves as two different sets of management practices, the initial thought was constructing a second-order reflective-formative construct. Based on this, we proposed the following measures (shown in Table 1).

Table 1. Initial Measures for Sales and PPC derived from Literature

\begin{tabular}{|c|c|c|}
\hline Code & Description of Measures (PPC) & Key References \\
\hline PPC1 & We implement a systematic method of workload control & Hendry et al. (2013) \\
\hline PPC2 & $\begin{array}{l}\text { We employ a pre-shop floor pooling and release system to improve } \\
\text { flow in manufacturing operations }\end{array}$ & Thurer et al. (2012) \\
\hline PPC3 & We have a systematic method of bottleneck detection and reduction & Petroni et al. (2017) \\
\hline PPC4 & Job priorities are clearly understood by everyone on the shop floor & $\begin{array}{l}\text { Muda and Hendry } \\
\text { (2003) }\end{array}$ \\
\hline PPC5 & $\begin{array}{l}\text { We rigorously pursue quick change over and set-up times for our } \\
\text { machines and strive to improve them }\end{array}$ & $\begin{array}{l}\text { Muda and Hendry } \\
\text { (2003), Petroni et al. } \\
\text { (2017) }\end{array}$ \\
\hline PPC6 & $\begin{array}{l}\text { We structure our manufacturing practices and shop-floor layout based } \\
\text { on the identification of common product families }\end{array}$ & Petroni et al. (2017) \\
\hline Sales1 & $\begin{array}{l}\text { We keep track of and monitor all quotation (both won and lost) in an } \\
\text { easy access database }\end{array}$ & $\begin{array}{l}\text { Muda and } \\
(2003)\end{array}$ \\
\hline Sales2 & $\begin{array}{l}\text { We have a keen understanding of our competitors and employ a } \\
\text { systematic quotation control system in order to help guide cost and } \\
\text { lead time estimations for customer enquiries (for example, a strike- } \\
\text { rate matrix) }\end{array}$ & $\begin{array}{l}\text { Muda and Hendry } \\
\text { (2003) }\end{array}$ \\
\hline Sales3 & $\begin{array}{l}\text { We actively help customers meet their goals rather than just } \\
\text { providing customers' wants }\end{array}$ & $\begin{array}{l}\text { Muda and Hendry } \\
\text { (2003) }\end{array}$ \\
\hline Sales4 & $\begin{array}{l}\text { There is a high degree of coordination between all departments to } \\
\text { ensure we set realistic due dates for customer enquiries }\end{array}$ & Zorzini et al. (2008) \\
\hline Sales5 & $\begin{array}{l}\text { Capacity and resource availability information is readily available to } \\
\text { both manufacturing and sales departments when responding to } \\
\text { customer enquiries }\end{array}$ & Kingsman et al. (1996) \\
\hline Sales6 & $\begin{array}{l}\text { There is a high degree of coordination between our organisation and } \\
\text { our suppliers when we respond to customer enquiries }\end{array}$ & Zorzini et al. (2008) \\
\hline
\end{tabular}


These measures were then used in a content validity test based on the CVI (See Appendix B). There is relative convergence amongst the subject matter experts in understanding the items to their respective constructs. However, a cross-validation exercise involving a post-hoc literature review prompted by comments from the study participants revealed a discrepancy concerning items PPC5 and PPC6.

Quick change-over and setup times seem valid for machining and tooling HVLV manufacturers, though appeared less relevant for those in heavy fabrication. Similarly, the restructure of the shopfloor to suit common product families does not appear relevant in versatile manufacturing companies where repeat business is often not possible. For these reasons, PPC5 and PPC6 were removed. PPC2 can also be considered a subset of PPC1. To avoid confusion, and for the sake of simplification, PPC2 was also removed, leaving PPC1, PPC3, and PPC4. Given these three items stem from the concept of workload control in HVLV manufacturing (Hendry et al. 2013), the construct's name was also changed to suit.

In terms of the items associated with the Sales construct, Sales3, whilst a prevalent item in HVLV manufacturing literature (Petroni et al. 2017), required simplification according to the same discussions held after the content validity questionnaire. In this instance, Sales3 was modified to read "we understand our customers' objectives." Furthermore, Sales itself held two distinct activities in Quotation Management (Sales 1-3) and Coordination (Sales 4-6).

Appendix A presents the final measures for the PPC construct.

\section{Human Resource Management}

HRM literature provides an exhaustive list of management practices that appear better than others at delivering organisational performance outcomes (Úbeda-García et al. 2018). Because we adopt the notion of BMP, it would be fitting to adopt similar measures as those within the domain. Thus, our measures of HRM practices were adapted from the mass-scale survey studies on BMP (Bloom and Van Reenen 2006, Agarwal et al. 2014). Hence, we adapted the more qualitative scale developed by Bloom and Van Reenen (2006).

Considering measures were adapted into this research context, achieving content validity required more than an extensive literature review process. Hence, the CVI was calculated in this case (shown in Appendix B).

The results suggest that the scale needs some adjustment. The S-CVI is below the recommended threshold of 0.8 (Polit and Beck 2006). It is also apparent that HRM2 and HRM3 require further 
attention from their low modified Kappa statistic. Like PPC, a post-hoc validation exercise through reviewing comments made by the participants in the CVI study revealed that HRM2 and HRM3 required revised measures, which were more comprehensible and reflect the consensus amongst HRM authorship in general (see details in Appendix A).

\subsection{Survey Design and Data Collection}

The final survey was split into four sections. Section A collected both generic organisational characteristics such as size and those more specific to HVLV manufacturing (e.g. product characteristics). Section B, C, and D all adopted a five-point Likert scale for analysis. Section B focussed on the extent to which BMP was adopted in the organisation while Section C was used to grasp the extent of ambidextrous capabilities the HVLV manufacturer held. Lastly, Section D was used to discern the HVLV manufacturers performance.

Given the increased risk of higher non-response rates and the nature of the research as an inherently strategic enquiry, as with other studies in this domain (c.f. Kortmann et al. 2014), we adopt the key informant approach where the survey was sent to single key-decision makers in HVLV manufacturers within Australia. Even though single key respondents are particularly useful in research concerning organisational phenomena in SMEs, self-reporting bias in single informant studies remains a concern (Flynn et al. 2018). To combat this, we implemented multiple measures that included 1) an invitation letter that was both appealing to manufacturers and demonstrated good research practice, 2) providing official research documentation (approvals and ethics documents), 3) providing incentives and promotions by way of a personalised executive summary and discounted entry to academic conferences and 4) randomised and carefully structured questions so as to avoid any sensitivity issues.

Once a pilot study was conducted - using five academics and one HVLV manufacturing industry professional for feedback - the survey was delivered using multiple delivery methods. Firstly, a list of 415 HVLV manufacturers was developed using a free online business directory and search terms based on ANZSIC codes that most resembled HVLV manufacturers. Similar to the approach adopted by Salvador and Forza (2004), expert judgement, by way of one authors' practical experience in HVLV manufacturing, as well as the characterisation of HVLV manufacturers in literature were used to identify the following ANZSIC codes: $2741,2759,2864$. Cold calling was then deemed appropriate to maximise the response rate through conjuring interest in the research and building a rapport with potential respondents. Those that responded favourably provided direct email addresses to key decision makers. Out of 106 HVLV manufacturers that were contacted, 63 provided valid emails and 11 responses were received. A decision was then taken to email the remaining HVLV manufacturers 
gathered from the business directory using publicly available contact information. Thus, 309 survey invitations were sent, and 36 responses were returned.

A mailing list was then purchased from a list broker tailored to the ANZSIC codes used previously. 756 invitations were sent and only three responses were received. The survey management tool used to deliver the questionnaire indicated that only 138 emails reached their intended recipients, the rest had either bounced back or remained unopened. It was evident that the majority of emails were not personalised to any one individual and, as was the case for Aslan et al. (2015), significantly reduced the effectiveness of this approach. A specialist list broker was thus approached to provide personalised emails for key decision makers in HVLV manufacturing organisations, again based on the initial ANZSIC codes. Here, 328 invitations were sent, and 23 completed responses were received.

After four rounds of data collection (with each round consisting of three reminder emails two weeks apart), 838 survey invitations were successfully sent. We received 73 surveys, revealing an overall response rate of around 9\%, not uncommon for HVLV manufacturing research (Aslan et al. 2015).

After accounting for firms that had less than five employees (9), excessive missing data (13), and suspicious response patterns (1), a total of 23 questionnaires were removed from sample, leaving 50 valid responses.

\subsection{Respondent Profile and Descriptive Statistics}

Appendix C provides the respondent profile and generic organisational characteristics of HVLV manufacturers. Most respondents appeared to be key decision makers in HVLV manufacturers while the remainder of the sample consisted of middle management positions, including those related to estimation and sales.

In HVLV manufacturing, middle management typically refers to department heads (e.g., fabrication manager and machine shop manager) that hold key decisions in resource allocation and workrouting (c.f. Clegg and Fitter 1981). The project-based nature of operations means that most day-today problem-solving activities are undertaken by these middle managers, indicating their in-depth knowledge of operational phenomena. In a strategic sense, it is also important to note that strategic decisions in a HVLV manufacturing environment typically concern job acceptance, sales, and estimation decisions (Kingsman et al. 1996). Thus, the entry into new markets and the decision to build capabilities underline the job opportunities in a season. Middle management is critical here as they present the conduit from which strategic decisions are developed and enacted (Wolf and Floyd 2017); thus, the efficacy of strategic decision making also depends on them. 
In terms of organisational characteristics, consistent with extant HVLV manufacturing literature (Stevenson et al. 2005), most of the sample consisted of well-established firms that fit an SME profile, less than 200 employees. Also, the HVLV manufacturers in this sample serviced a variety of industries (16 in total), most of which include the manufacture of sheet metal and structural steel products (16\% each), agricultural machinery and equipment (11\%), mining and construction machinery $(11 \%)$ as well as the manufacturer of machine tools and parts (9\%).

In line with our characterisation of HVLV manufacturing, all respondents undertook some level of customisation activities with $38 \%$ undertaking extensive customisation work where each product is different from the other and there are no repeat orders; $36 \%$ undertaking extensive customisation work as above, however, with some degree of repetition; $22 \%$ making a mixture of custom and standard products; and only $4 \%$ manufacturing primarily standardised products.

\section{Analysis and Results}

The research model was assessed using partial least squares structural equation modelling (PLS SEM). Apart from the commonly cited advantages in dealing with smaller sample sizes (Hair et al. 2019), as a variance-based approach adopted in a variety of research settings (Peng and Lai 2012, Ringle et al. 2012), it is also regarded to be a robust analysis technique in studies concerning management practices given its ability to model both composites and factors (Peng and Lai 2012) as well as those characterised by formative-reflective measures (Hair et al. 2017).

As with other PLS studies with relatively small sample sizes (Agarwal et al. 2018), we adopt a dualstage approach in our analysis by firstly assessing the reliability and validity of the measurement (outer) model, followed by an assessment of the structural (inner) model. The analysis of the PLS SEM model was conducted using SmartPLS 3 software.

\subsection{Evaluation of the Measurement Model}

The measurement model was evaluated based on the type of relationship between indicators and their constituent variables. For reflective measures, indicator loadings, internal consistency reliability, convergent validity, and discriminant validity are assessed (Hair et al. 2019).

As the table in Appendix A demonstrates, most indicators had reasonable factor loadings (ranging from 0.611 to 0.944 ) - given values greater than 0.7 are generally regarded as acceptable (Peng and Lai 2012). Removal of some indicators in the region of 0.611 resulted in minor improvements towards internal consistency reliability, which posed concerns over convergent validity and were thus retained. However, the indicator HRM6 observed a loading of 0.489 , which was far below the recommended guidelines and was removed. Internal consistency reliability was measured according 
to both the composite reliability of the measure and the $P_{A}$ value. Here, all values lied between approximately 0.6 and 0.95 , also demonstrating good internal consistency reliability (Hair et al. 2017). Convergent validity was assessed based on the average variance extracted (AVE) where all measures observed values greater than 0.5 - thus, acceptable. Finally, discriminant validity was assessed by using the more contemporary heterotrait-monotrait (HTMT) ratio where correlations between variables should be less than one (Henseler et al. 2015) (See Appendix D).

A different approach is undertaken to assess the reliability and validity of the second-order reflective-formative factors in the model. Here, collinearity and statistical significance, and relevance are typically assessed (Hair et al. 2019). Collinearity is assessed using the variance inflation factor (VIF) and a bias-corrected accelerated (BCa) bootstrapping procedure using 5000 subsamples for testing the statistical significance and relevance. As Table 2 illustrates, all VIF values for the secondorder constructs are less than three, thus demonstrating collinearity is not problematic (Hair et al. 2017). Besides, the respective $t$ and $p$ statistics resemble those of statistical relevance and significance - further indicating the reliability and validity of these higher-order constructs.

Table 1 Second-Order Reflective-Formative Measure Evaluation

\begin{tabular}{llll} 
& Weights & T-values & VIF \\
\hline Ambidexterity & & & 1.891 \\
Exploration & 0.558 & $11.540^{* * *}$ & 1.891 \\
Exploitation & 0.530 & & \\
PPL & & $9.044^{* * *}$ & 2.113 \\
Quotation Management & 0.331 & $10.729 * * *$ & 2.000 \\
Workload Control & 0.437 & $11.531 * * *$ & 1.852 \\
Coordination & 0.400 & & \\
$* * * p<0.001$ & & &
\end{tabular}

\subsection{Evaluation of the Structural Model}

The structural model evaluation was conducted using Smart PLS 3 based on recommended guidelines for organisation research by Hair et al. (2017). Here, 5000 subsamples were adopted using a BCa procedure based on a significance level of 0.05 and two-tailed testing. The results of the direct relationships in the structural model assessment are shown in Table 3, including the effects of control variables.

Table 2 PLS SEM Results for Direct Relationships with Control Variables

Confidence Interval

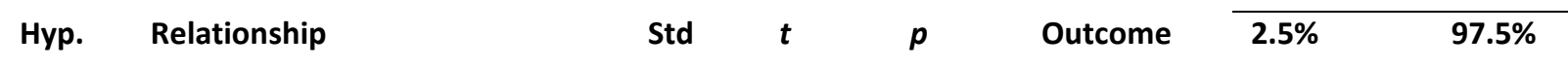




\begin{tabular}{|c|c|c|c|c|c|c|c|}
\hline & & & & & & & \\
\hline & & Beta & value & value & & & \\
\hline $\mathrm{H} 1 \mathrm{a}$ & Ambidexterity $\rightarrow$ HRM & 0.653 & 4.698 & 0.000 & Supported & 0.312 & 0.833 \\
\hline $\mathrm{H} 1 \mathrm{~b}$ & HRM $\rightarrow$ Operational Flexibility & -0.055 & 0.379 & 0.705 & Not Supp. & -0.345 & 0.222 \\
\hline & & & & & & Confide & terval \\
\hline & & Std & $\boldsymbol{t}$ & $p$ & & & \\
\hline Hyp. & Relationship & Beta & value & value & Outcome & $2.5 \%$ & $97.5 \%$ \\
\hline & Age -> HRM & 0.101 & 0.879 & 0.380 & Not Sign. & -0.131 & 0.330 \\
\hline & Age $->$ PPC & 0.261 & 1.791 & 0.073 & Not Sign. & -0.050 & 0.524 \\
\hline & Age -> Operational Flexibility & -0.037 & 0.336 & 0.737 & Not Sign. & -0.264 & 0.178 \\
\hline & Age $->$ Process Innovation & 0.076 & 0.623 & 0.533 & Not Sign. & -0.173 & 0.313 \\
\hline & Size -> HRM & 0.005 & 0.038 & 0.970 & Not Sign. & -0.252 & 0.260 \\
\hline & Size -> PPC & -0.130 & 1.238 & 0.216 & Not Sign. & -0.325 & 0.080 \\
\hline
\end{tabular}

\begin{tabular}{|c|c|c|c|c|c|c|c|}
\hline $\mathrm{H} 1 \mathrm{c}$ & HRM $\rightarrow$ Process Innovation & 0.484 & 3.140 & 0.002 & Supported & 0.185 & 0.796 \\
\hline $\mathrm{H} 2 \mathrm{a}$ & Ambidexterity $\rightarrow$ PPC & 0.646 & 4.698 & 0.000 & Supported & 0.307 & 0.842 \\
\hline $\mathrm{H} 2 \mathrm{~b}$ & PPC $\rightarrow$ Operational Flexibility & 0.492 & 3.257 & 0.001 & Supported & 0.218 & 0.810 \\
\hline \multirow[t]{2}{*}{$\mathrm{H} 2 \mathrm{C}$} & PPC $\rightarrow$ Process Innovation & 0.012 & 0.063 & 0.950 & Not Supp. & -0.381 & 0.341 \\
\hline & Ambidexterity $\rightarrow$ Operational & & & & & & \\
\hline $\mathrm{H} 3 \mathrm{a}$ & Flexibility & 0.188 & 1.054 & 0.292 & Supported & -0.201 & 0.486 \\
\hline $\mathrm{H} 3 \mathrm{~b}$ & $\begin{array}{l}\text { Ambidexterity } \rightarrow \text { Process } \\
\text { Innovation }\end{array}$ & 0.120 & 0.661 & 0.509 & Supported & -0.253 & 0.461 \\
\hline
\end{tabular}




\begin{tabular}{lllllll} 
Size $->$ Operational Flexibility & 0.263 & 2.542 & 0.011 & Significant & 0.073 & 0.479 \\
Size $->$ Process Innovation & -0.034 & 0.275 & 0.784 & Not Sign. & -0.250 & 0.246 \\
Construct & $\mathbf{R}^{2} \mathbf{A d j}$. & $\mathbf{Q}^{2}$ & & & & \\
\hline HRM & 0.381 & 0.291 & & & \\
PPC & 0.401 & 0.324 & & \\
Operational Flexibility & 0.344 & 0.261 & & \\
Process Innovation & 0.256 & 0.127 & &
\end{tabular}

Mediation analysis was undertaken by investigating the specific indirect effects within SmartPLS 3. Understanding the limitations of traditional, piecemeal approaches to mediation analysis (Zhao et al. 2010), and in line with more recent PLS SEM studies with relatively small sample sizes (e.g. Agarwal et al. 2018), we have opted to test for parallel mediation based on the entire model by a bootstrapping procedure similar to that described in the test for direct relationships earlier. The results of this analysis are shown in Table 4.

Table 3 PLS SEM Mediation Analysis

\begin{tabular}{|c|c|c|c|c|c|c|}
\hline Indirect Relationship & $\begin{array}{l}\text { Std } \\
\text { Beta }\end{array}$ & t-value & p-value & Outcome & $\begin{array}{l}97.5 \% \\
\mathrm{CI} L \mathrm{~L}\end{array}$ & $\begin{array}{l}97.5 \% \\
\mathrm{CI} U L\end{array}$ \\
\hline \multicolumn{7}{|l|}{ Ambidexterity -> HRM } \\
\hline -> Flexibility & -0.036 & 0.369 & 0.712 & No Mediation & -0.240 & 0.149 \\
\hline \multicolumn{7}{|l|}{ Ambidexterity -> HRM } \\
\hline -> Process Innovation & 0.316 & 2.445 & 0.015 & Full Mediation & 0.087 & 0.581 \\
\hline \multicolumn{7}{|l|}{ Ambidexterity $->$ PPC } \\
\hline -> Flexibility & 0.318 & 2.332 & 0.02 & Full Mediation & 0.103 & 0.626 \\
\hline \multicolumn{7}{|l|}{ Ambidexterity -> PPC } \\
\hline -> Process Innovation & 0.008 & 0.061 & 0.952 & No Mediation & -0.270 & 0.232 \\
\hline
\end{tabular}

\subsection{Common Method Bias}

Given the research design involves a single respondent in each organisation, a post-hoc analysis for common method bias was conducted. To accomplish this, and in line with Kortmann et al. (2014), Harman's single factor test was adopted (Podsakoff and Organ 1986). Here, we assess the extent to which a single factor accounts for the majority of the variance. Based on an unrotated principal component analysis concerning all items used in the model, the results suggest that $33.657 \%$ of the variance can be explained by one factor. Thus, common method bias does not seem to be problematic. 


\section{Discussion and Conclusions}

\subsection{Implications to Theory}

In general, our results resemble the configurational approach to DC (Wilden et al. 2016) in the role of higher-order (dynamic) capabilities in some way shaping lower-order or operational (Helfat and Winter 2011, Winter 2003) routines which subsequently impact organisational performance outcomes (Protogerou et al. 2011, Waleczek et al. 2019). This presents some contrast towards other proponents of the capabilities-based theory of the firm whereby ordinary capabilities (BMP) may not be as crucial to competitive advantage as DC. For example, a firm with good DC and poor ordinary capabilities, will presumably outlast a firm with poor DC and excellent ordinary capabilities (Teece 2017). Such a perspective, however, also recognises the key role management practices play in this relationship, suggesting that this is only the "tip of the iceberg in the way that management matters"(Teece 2017, p. 23). We intend to begin to shed some light on what lies beneath.

Firstly, our results concerning the positive impact of ambidextrous (dynamic) capabilities on BMP are consistent with the broader notion that DC plays a crucial role in the implementation process of adoptive managerial innovations, i.e., those that already exist and are readily identifiable (Lin et al. 2016). Here, we add to the emerging viewpoint that DC helps an organisation seek-out, assess, and enact BMP (Khosravi et al. 2019), thus increasing the odds of adoption (Lin et al. 2016). This view also aids in understanding BMP as complementary lower-order capabilities given the higher-order counterpart typically helps in achieving a greater appreciation and awareness of their use in practice (Schilke 2014).

Besides, the fully mediating role of BMP in the link between ambidextrous capabilities and organisational performance outcomes we uncovered also conforms to recent arguments in the broader DC literature concerning the mediating role of ordinary capabilities in the link between DC and organisational performance (c.f. Waleczek et al. 2019). This also provides some strength to the more conceptual discussions on ambidexterity as a higher-order capability (Zimmermann and Birkinshaw 2016) and flips the narrative of BMP in helping to build ambidextrous capabilities (e.g. Matthews et al. 2015), to one where BMP play a more central role in the deployment of the capability throughout the organisation. This relationship, however, appears contingent on the characteristics of the BMP themselves, showing two possible "dynamic bundles" (Waleczek et al. 2019) that impact organisational performance differently.

PPC practices demonstrated a fully mediating relationship with operational flexibility. However, contrary to PPC notions as an inherently innovative exercise in HVLV manufacturing (Petroni et al. 2017), our results did not support the latter. Similarly, with HRM practices, whereby process 
innovation was impacted, and operational flexibility was not. Thus, whilst we can contend that pursuing a mutually synergistic relationship between exploratory and exploitative activities can emerge through PPC and HRM, the way this DC becomes embedded in these BMP leaves their outcomes open to the idiosyncrasies associated with their application in practice.

Furthermore, this paper substantiates the conceptual arguments presented in earlier work by Katic et al. (2019) concerning the potential for BMP to help HVLV manufacturers in deploying ambidexterity. Building off the apparent bias towards exploitation in HVLV manufacturing literature (Katic and Agarwal 2018), we extend these contributions by empirically demonstrating the dualnature of capability investments in ambidexterity and BMP towards exploratory and exploitative HVLV manufacturer performance outcomes. This finding carries significant implications for HVLV manufacturing practitioners.

\subsection{Implications for Managers}

The research presented herein poses a fundamentally practice-based question. Even though it is general in understanding how ambidextrous capabilities can be deployed through BMP, the HVLV manufacturing case poses beneficial managerial guidelines for key decision-makers.

Firstly, we highlight the peculiarities of successfully running a highly flexible manufacturing organisation. We illustrate how the flexibility inherent in HVLV manufacturing enterprises can be to their detriment. On the one hand, flexibility can cause such organisations to revert to exploitative measures to counter environmental dynamism inadvertently. On the other hand, flexibility brings exploration and forfeit opportunities to build capabilities necessary to compete in the short-term (Katic and Agarwal 2018). Indeed, both are required, and, as we have demonstrated, ambidextrous capabilities drive the adoption of BMP. For managers, this means maximizing the tensions brought forward when undertaking each project towards synergistic outcomes - proving crucial to the pursuit of long-term competitive advantage through the adoption of BMP.

Secondly, PPC and HRM have observed increased attention from researchers in HVLV manufacturing (Petroni et al. 2017). Though, it appears their contradictory effects have been somewhat taken for granted. In the case of PPC, for instance, the classic "job shop problem" and "lead-time syndrome" have been plaguing researchers for decades (Stevenson et al. 2005). This paper aims to improve visibility, increase responsiveness to change, and improve decision-making capabilities for managers by helping make sense of the chaos in a more meaningful manner (Stevenson and Vanharanta 2015). However, we urge HVLV managers to carefully consider adopting PPC measures while proving crucial in leveraging their ambidexterity capabilities and increasing their ability to make a host of highly customised products. Since these capabilities also prove to be a barrier to ongoing operational 
renewal. Thus, while PPC measures help HVLV organisations do things right, they do not necessarily help do the right things.

In the case of HRM practices, it would appear to be the opposite. Again, proving crucial in leveraging their ambidexterity towards favourable performance outcomes appears detrimental when operational flexibility is concerned. We would recommend the selective use of these measures. However, there is more to this phenomenon stemming from the heterogeneity in HVLV manufacturing enterprises themselves (Amaro et al. 1999). While this claim cannot be substantiated from the evidence provided thus far, we can attest that HRM practices may see decreased relevance in HVLV manufacturing associated with more repeat business than those that conduct engineering activities more often.

\subsection{Limitations and Potential for Further Research}

While demonstrating significance across multiple domains in ambidexterity, operations, and HVLV manufacturing literature, this paper is not without its limitations.

Firstly, this research's comparatively small sample size has constrained overall generalisability and limited the capabilities in adopting more advanced inference techniques to cover a wide suite of BMP. Though meeting the minimum sample size requirements in terms of model complexity and size (see the post-hoc power assessment in Hair et al. 2017), care should be taken to interpret these results, particularly when full mediation is concerned (Rucker et al. 2011).

Secondly, although measures were taken to reduce common method bias and self-reporting through the research design, a single key decision-maker was surveyed. Ambidexterity occurs at multiple levels of organisation (Birkinshaw and Gupta 2013). Thus a richer understanding can be obtained by investigating how ambidexterity can manifest at different organization levels. Further research could also extend our contributions by adopting a longitudinal research method based on an organisation's ambidexterity journey over time.

Third, further research is required to test the maximisation perspective of ambidexterity in HVLV manufacturers. Whilst we can certainly attest to this perspective's credibility, both theoretically and empirically, there lies an opportunity to strengthen these findings by adopting different perspectives on ambidextrous capabilities (Luger et al. 2018).

Finally, context plays an essential role in both the characterisation of HVLV manufacturers and BMP. HVLV manufacturing strategies can span both engineer-to-order and make-to-order strategies (Katic and Agarwal 2018). Further research is encouraged to substantiate these nuances. 


\section{Appendix A: Measurement Model Evaluation (Reflective Constructs)}

\begin{tabular}{|c|c|c|c|c|c|c|c|}
\hline Construct & Items & Description & Status & Loadings & AVE & CR & Rho A \\
\hline Exploitation* & Exploit1 & We commit to improving quality and lowering costs & Adopted & 0.699 & 0.548 & 0.861 & 0.818 \\
\hline \multirow[t]{4}{*}{ (Lubatkin et al. 2006) } & Exploit2 & $\begin{array}{l}\text { We strive to continuously improve the reliability of our products } \\
\text { and/or services }\end{array}$ & Adopted & 0.802 & & & \\
\hline & Exploit4 & $\begin{array}{l}\text { We constantly questionnaire the customer satisfaction levels of our } \\
\text { existing customer base }\end{array}$ & Adopted & 0.673 & & & \\
\hline & Exploit5 & We fine-tune what we offer to keep our current customers satisfied & Adopted & 0.835 & & & \\
\hline & Exploit6 & $\begin{array}{l}\text { We place focus on penetrating more deeply into our existing } \\
\text { customer base }\end{array}$ & Adopted & 0.679 & & & \\
\hline Exploration* & Explore1 & We look for novel technological ideas by thinking outside the box & Adopted & 0.774 & 0.556 & 0.858 & 0.809 \\
\hline \multirow[t]{4}{*}{ (Lubatkin et al. 2006) } & Explore2 & We base our success on our ability to explore new technologies & Adapted & 0.747 & & & \\
\hline & Explore4 & We look for creative ways to satisfy our customer needs & Adapted & 0.83 & & & \\
\hline & Explore5 & We aggressively venture into new market segments & Adopted & 0.749 & & & \\
\hline & Explore6 & We actively target new customer groups & Adapted & 0.611 & & & \\
\hline HRM* & HRM1 & $\begin{array}{l}\text { Senior managers are evaluated and held accountable for the } \\
\text { strength of the talent pool they actively build }\end{array}$ & Adapted & 0.643 & 0.520 & 0.843 & 0.797 \\
\hline \multirow[t]{4}{*}{ (Bloom and Van Reenen 2006) } & HRM2 & $\begin{array}{l}\text { We adopt an appropriate performance-based rewards and } \\
\text { accountability system linked to organisational targets }\end{array}$ & Adapted & 0.706 & & & \\
\hline & HRM3 & $\begin{array}{l}\text { We adopt different strategies (remove, reallocate and/or develop } \\
\text { employees) to manage our underperformers }\end{array}$ & Adapted & 0.682 & & & \\
\hline & HRM4 & We actively identify, develop and promote our top performers & Adapted & 0.754 & & & \\
\hline & HRM5 & We provide a unique value proposition above our competitors to & Adapted & 0.810 & & & \\
\hline
\end{tabular}




\begin{tabular}{|c|c|c|c|c|c|c|c|}
\hline Construct & Items & Description & Status & Loadings & AVE & CR & Rho A \\
\hline & & encourage talented people to join our company & & & & & \\
\hline Quotation Management & Sales1 & $\begin{array}{l}\text { We keep track of and monitor all quotation (both won and lost) in } \\
\text { an easy access database }\end{array}$ & Adapted & 0.717 & 0.546 & 0.782 & 0.599 \\
\hline \multirow[t]{2}{*}{ (See Table 1 for key references) } & Sales2 & $\begin{array}{l}\text { We have a keen understanding of our competitors and employ a } \\
\text { systematic quotation control system in order to help guide cost and } \\
\text { lead time estimations for customer enquiries (for example, a strike- } \\
\text { rate matrix) }\end{array}$ & Adapted & 0.818 & & & \\
\hline & Sales3 & We understand our customers' objectives & Adapted & 0.674 & & & \\
\hline Coordination & Sales4 & $\begin{array}{l}\text { There is a high degree of coordination between all departments to } \\
\text { ensure we set realistic due dates for customer enquiries }\end{array}$ & Adapted & 0.828 & 0.690 & 0.87 & 0.789 \\
\hline \multirow[t]{2}{*}{ (See Table 1 for key references) } & Sales5 & $\begin{array}{l}\text { Capacity and resource availability information is readily available to } \\
\text { both manufacturing and sales departments when responding to } \\
\text { customer enquiries }\end{array}$ & Adapted & 0.857 & & & \\
\hline & Sales6 & $\begin{array}{l}\text { There is a high degree of coordination between our organisation and } \\
\text { our suppliers when we respond to customer enquiries }\end{array}$ & Adapted & 0.807 & & & \\
\hline WLC & PPC1 & We implement a systematic method of workload control & Adapted & 0.875 & 0.758 & 0.904 & 0.840 \\
\hline \multirow[t]{2}{*}{ (See Table 1 for key references) } & PPC3 & We have a systematic method of bottleneck detection and reduction & Adapted & 0.853 & & & \\
\hline & PPC4 & Job priorities are clearly understood by everyone on the shop floor & Adopted & 0.883 & & & \\
\hline Flexibility & Perf_Flex1 & (Ability to) customise products & Adopted & 0.665 & 0.605 & 0.857 & 0.960 \\
\hline \multirow[t]{3}{*}{ (Swink et al. 2005) } & Perf_Flex2 & Adjust production volumes & Adopted & 0.879 & & & \\
\hline & Perf_Flex3 & Respond to changes in delivery requirements & Adopted & 0.904 & & & \\
\hline & Perf_Flex4 & Produce a range of products & Adopted & 0.624 & & & \\
\hline Process Innovation & $\begin{array}{l}\text { Perf_Innov } \\
\text { Proc1 }\end{array}$ & Technological competitiveness & Adopted & 0.861 & 0.79 & 0.937 & 0.920 \\
\hline
\end{tabular}




\begin{tabular}{|c|c|c|c|c|c|c|c|}
\hline Construct & Items & Description & Status & Loadings & AVE & CR & Rho A \\
\hline \multirow[t]{3}{*}{ (Prajogo and Sohal 2003) } & $\begin{array}{l}\text { Perf_Innov } \\
\text { Proc2 }\end{array}$ & Novelty of technology used & Adopted & 0.885 & & & \\
\hline & $\begin{array}{l}\text { Perf_Innov } \\
\text { _Proc3 }\end{array}$ & Speed of adoption of latest technology & Adopted & 0.944 & & & \\
\hline & $\begin{array}{l}\text { Perf_Innov } \\
\text { _Proc4 }\end{array}$ & The rate of change in processes and technology & Adopted & 0.862 & & & \\
\hline
\end{tabular}

*Exploit3, Explore3, HRM6 and PPC4 removed due to validity and reliability concerns.

${ }^{a}$ Loadings $<0.600$ were dropped ${ }^{b}$ AVE $<0.5000{ }^{c}$ CR $<0.700{ }^{d}$ Rho $A<0.6$ 
Appendix B: Results of the content validity testing for production planning and control and human resource management constructs

\begin{tabular}{lcllll} 
Code & No. of 4-5 rating & $\mathbf{I - C V I * *}$ & $\mathbf{P}_{\mathbf{c}}^{* * *}$ & $\mathbf{K}^{* * * *}$ & Interpretation \\
\hline Sales1 & 10 & 0.769 & 0.070 & 0.752 & Excellent \\
Sales2 & 10 & 0.769 & 0.070 & 0.752 & Excellent \\
Sales3 & 8 & 0.615 & 0.314 & 0.439 & Fair \\
Sales4 & 12 & 0.923 & 0.003 & 0.923 & Excellent \\
Sales5 & 13 & 1 & 0 & 1 & Excellent \\
Sales6 & 9 & 0.692 & 0.175 & 0.627 & Good \\
& S-CVI (Average)* & 0.795 & & &
\end{tabular}

\begin{tabular}{lcllll} 
Code & No. of 4-5 rating & I-CVI** & $\mathbf{P}_{\mathbf{c}}^{* * *}$ & $\mathbf{K}^{* * * *}$ & Interpretation \\
\hline PPC1 & 12 & 0.923 & 0.003 & 0.923 & Excellent \\
PPC2 & 11 & 0.846 & 0.019 & 0.843 & Excellent \\
PPC3 & 12 & 0.923 & 0.003 & 0.923 & Excellent \\
PPC4 & 12 & 0.923 & 0.003 & 0.923 & Excellent \\
PPC5 & 13 & 1 & 0 & 1 & Excellent \\
PPC6 & 12 & 0.923 & 0.003 & 0.923 & Excellent \\
& S-CVI (Average)* & 0.923 & & &
\end{tabular}

\begin{tabular}{lcclll} 
Code & No. of 4-5 rating & I-CVI** & $\mathbf{P}_{\mathbf{c}}^{* * *}$ & $\mathbf{K}^{* * * *}$ & Interpretation \\
\hline HRM1 & 12 & 0.923 & 0.003 & 0.923 & Excellent \\
HRM2 & 7 & 0.538 & 0.419 & 0.206 & Poor \\
HRM3 & 6 & 0.462 & 0.419 & 0.073 & Poor \\
HRM4 & 11 & 0.846 & 0.019 & 0.843 & Excellent \\
HRM5 & 12 & 0.923 & 0.003 & 0.923 & Excellent \\
HRM6 & 11 & 0.846 & 0.019 & 0.843 & Excellent \\
& S-CVI (Average)* & 0.756 & & &
\end{tabular}

${ }^{*} \mathrm{~S}-\mathrm{CVI}$ is the scale content validity index, ${ }^{*} \mathrm{I}-\mathrm{CVI}$ is the individual content validity index, ${ }^{* * *} \mathrm{P}_{\mathrm{c}}$ is the probability of chance occurrence, ${ }^{* * * *} \mathrm{~K}$ is the modified Kappa statistic where 0.74 is excellent, 0.6-0374 is good and values from 0.59-0.4 can be considered fair. 


\section{Appendix C: Respondent Profile and Descriptive Statistics}

\begin{tabular}{|c|c|c|}
\hline Respondent Descriptive Statistics & $\mathbf{N}$ & $\%$ (rounded) \\
\hline \multicolumn{3}{|l|}{ Role } \\
\hline CEO/Owner/Director & 31 & 62 \\
\hline General Manager & 12 & 24 \\
\hline Middle Management & 4 & 8 \\
\hline Other & 3 & 6 \\
\hline \multicolumn{3}{|l|}{ Tenure (years) } \\
\hline Less than 5 & 8 & 16 \\
\hline $5-10$ & 8 & 16 \\
\hline $11-15$ & 12 & 24 \\
\hline $16-20$ & 6 & 12 \\
\hline More than 20 & 16 & 32 \\
\hline Generic Organisational Descriptive Statistics & $\mathbf{N}$ & $\%$ (rounded) \\
\hline \multicolumn{3}{|l|}{ Size (No. of employees) } \\
\hline $5-19$ & 29 & 58 \\
\hline 20-99 & 19 & 38 \\
\hline 100-199 & 2 & 4 \\
\hline \multicolumn{3}{|l|}{ Age (years operational) } \\
\hline $5-10$ & 1 & 2 \\
\hline $11-15$ & 6 & 12 \\
\hline $16-20$ & 7 & 14 \\
\hline More than 20 & 36 & 72 \\
\hline
\end{tabular}




\section{Appendix D: Discriminant validity testing using the heterotrait-}

\section{monotrait ratio}

\begin{tabular}{|c|c|c|c|c|c|c|c|c|c|c|}
\hline & $\underset{\leftarrow}{\stackrel{0}{\alpha}}$ & $\begin{array}{l}\frac{.}{0} \\
\frac{0}{\pi} \\
.0 \\
\frac{0}{0} \\
0 \\
0\end{array}$ & $\sum_{\substack{\text { I } \\
\text { I }}}$ & 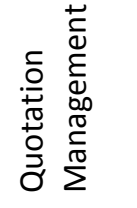 & $\stackrel{N}{\sim}$ & 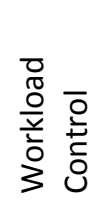 & 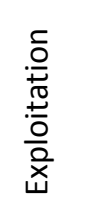 & $\begin{array}{l}\frac{.}{+} \\
\frac{\pi}{0} \\
\frac{0}{0} \\
\frac{1}{x}\end{array}$ & 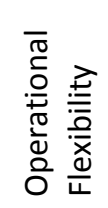 & 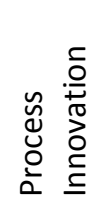 \\
\hline \multicolumn{11}{|l|}{ Age } \\
\hline Coordination & 0.128 & & & & & & & & & \\
\hline HRM & 0.106 & 0.516 & & & & & & & & \\
\hline Quotation Management & 0.279 & 0.872 & 0.595 & & & & & & & \\
\hline Size & 0.05 & 0.116 & 0.245 & 0.172 & & & & & & \\
\hline Workload Control & 0.176 & 0.644 & 0.582 & 0.941 & 0.107 & & & & & \\
\hline Exploitation & 0.137 & 0.688 & 0.808 & 0.738 & 0.104 & 0.638 & & & & \\
\hline Exploration & 0.179 & 0.614 & 0.65 & 0.498 & 0.248 & 0.447 & 0.82 & & & \\
\hline Operational Flexibility & 0.162 & 0.564 & 0.384 & 0.679 & 0.304 & 0.447 & 0.452 & 0.546 & & \\
\hline Process Innovation & 0.105 & 0.294 & 0.649 & 0.471 & 0.016 & 0.314 & 0.414 & 0.471 & 0.383 & \\
\hline
\end{tabular}

\section{References}

ABELL, P., FELIN, T. \& FOSS, N. 2008. Building micro-foundations for the routines, capabilities, and performance links. Managerial and decision economics, 29:6, 489-502.

ADLER, P. S., BENNER, M., BRUNNER, D. J., MACDUFFIE, J. P., OSONO, E., STAATS, B. R., TAKEUCHI, H., TUSHMAN, M. \& WINTER, S. 2009. Perspectives on the productivity dilemma. Journal of Operations Management, 27:2, 99-113.

ADRODEGARI, F., BACCHETTI, A., PINTO, R., PIROLA, F. \& ZANARDINI, M. 2015. Engineer-to-order (ETO) production planning and control: an empirical framework for machinery-building companies. Production Planning \& Control:ahead-of-print, 1-23.

AGARWAL, A., GIRAUD-CARRIER, F. C. \& LI, Y. 2018. A mediation model of green supply chain management adoption: The role of internal impetus. International Journal of Production Economics, 205, 342-358.

AGARWAL, R., BROWN, P. J., GREEN, R., RANDHAWA, K. \& TAN, H. 2014. Management practices of Australian manufacturing firms: why are some firms more innovative? International Journal of Production Research, 52:21, 6496-6517.

AMARO, G., HENDRY, L. \& KINGSMAN, B. 1999. Competitive advantage, customisation and a new taxonomy for non make-to-stock companies. International Journal of Operations \& Production Management, 19:4, 349-371.

ANAND, G., WARD, P. T., TATIKONDA, M. V. \& SCHILLING, D. A. 2009. Dynamic capabilities through continuous improvement infrastructure. Journal of operations management, 27:6, 444-461.

ANDRIOPOULOS, K., GUETTEL, W. H., KELLER, A. \& ZIMMERMANN, A. Microfoundations of Ambidexterity. Academy of Management Proceedings, 2018. Academy of Management Briarcliff Manor, NY 10510, 11483. 
ASLAN, B., STEVENSON, M. \& HENDRY, L. C. 2015. The applicability and impact of Enterprise Resource Planning (ERP) systems: Results from a mixed method study on Make-To-Order (MTO) companies. Computers in Industry, 70, 127-143.

BENNER, M. J. \& TUSHMAN, M. L. 2003. Exploitation, exploration, and process management: The productivity dilemma revisited. Academy of management review, 28:2, 238-256.

BENNER, M. J. \& TUSHMAN, M. L. J. A. O. M. R. 2015. Reflections on the 2013 Decade Award"Exploitation, exploration, and process management: The productivity dilemma revisited" ten years later. 40:4, 497-514.

BIRKIE, S. E., TRUCCO, P. \& KAULIO, M. 2017. Sustaining performance under operational turbulence: The role of Lean in engineer-to-order operations. International Journal of Lean Six Sigma, 8:4, 457-481.

BIRKINSHAW, J. \& GIBSON, C. B. 2004. Building an ambidextrous organisation. Advanced Institute of Management Research Paper:003.

BIRKINSHAW, J. \& GUPTA, K. 2013. Clarifying the distinctive contribution of ambidexterity to the field of organization studies. The Academy of Management Perspectives, 27:4, 287-298.

BLOOM, N., MAHAJAN, A., MCKENZIE, D. \& ROBERTS, J. 2018. Do management interventions last? evidence from India, The World Bank.

BLOOM, N. \& VAN REENEN, J. 2006. Measuring and explaining management practices across firms and countries. National Bureau of Economic Research.

BROMILEY, P. \& RAU, D. 2014. Towards a practice-based view of strategy. Strategic Management Journal, 35:8, 1249-1256.

CAO, Q., GEDAJLOVIC, E. \& ZHANG, H. 2009. Unpacking organizational ambidexterity: Dimensions, contingencies, and synergistic effects. Organization Science, 20:4, 781-796.

CARAYANNOPOULOS, S. 2017. Small, young firm flexibility and performance in the context of disruptive innovations. International Journal of Entrepreneurship and Innovation Management, 21:1-2, 105-118.

CLEGG, C. \& FITTER, M. 1981. Organizational and behavioural consequences of uncertainty. Journal of Organizational Behavior, 2:3, 155-175.

D'SOUZA, D. E., SIGDYAL, P. \& STRUCKELL, E. 2017. Relative ambidexterity: a measure and a versatile framework. The Academy of Management Perspectives, 31:2, 124-136.

EISENHARDT, K. M. \& MARTIN, J. A. 2000. Dynamic capabilities: what are they? Strategic management journal, 21:10-11, 1105-1121.

FELÍCIO, J. A., CALDEIRINHA, V. \& DUTRA, A. 2019. Ambidextrous capacity in small and medium-sized enterprises. Journal of Business Research, 101, 607-614.

FLYNN, B., PAGELL, M. \& FUGATE, B. 2018. Survey research design in supply chain management: the need for evolution in our expectations. Journal of Supply Chain Management, 54:1, 1-15.

FORZA, C. 2016. Surveys. In: KARLSSON, C. (ed.) Research Methods for Operations ManagementLondon, UK: Routledge.

HAIR, J. F., HULT, G. T. M., RINGLE, C. \& SARSTEDT, M. 2017. A Primer on Partial Least Squares Structural Equation Modeling (PLS-SEM), SAGE Publications.

HAIR, J. F., RISHER, J. J., SARSTEDT, M. \& RINGLE, C. M. 2019. When to use and how to report the results of PLS-SEM. European Business Review, 31:1, 2-24.

HAUG, A., LADEBY, K. \& EDWARDS, K. 2009. From engineer-to-order to mass customization. Management Research News, 32:7, 633-644.

HELFAT, C. E. \& WINTER, S. G. 2011. Untangling dynamic and operational capabilities: Strategy for the (N) ever-changing world. Strategic management journal, 32:11, 1243-1250.

HENSELER, J., RINGLE, C. M. \& SARSTEDT, M. 2015. A new criterion for assessing discriminant validity in variance-based structural equation modeling. Journal of the academy of marketing science, 43:1, 115-135. 
JANSEN, J. J., SIMSEK, Z. \& CAO, Q. 2012. Ambidexterity and performance in multiunit contexts: Cross-level moderating effects of structural and resource attributes. Strategic Management Journal, 33:11, 1286-1303.

JIANG, K., LEPAK, D. P., HAN, K., HONG, Y., KIM, A. \& WINKLER, A.-L. 2012. Clarifying the construct of human resource systems. Human Resource Management Review, 22:2, 73-85.

JUNNI, P., SARALA, R. M., TARAS, V. \& TARBA, S. Y. 2013. Organizational ambidexterity and performance: A meta-analysis. The Academy of Management Perspectives, 27:4, 299-312.

KATIC, M. \& AGARWAL, R. 2018. The Flexibility Paradox: Achieving Ambidexterity in High-Variety, Low-Volume Manufacturing. Global Journal of Flexible Systems Management, 1-18.

KATIC, M., CETINDAMAR, D., AGARWAL, R. \& SICK, N. Operationalising Ambidexterityg. 2019 Portland International Conference on Management of Engineering and Technology (PICMET), 2019. IEEE, 1-8.

KHOSRAVI, P., NEWTON, C. \& REZVANI, A. 2019. Management innovation: A systematic review and meta-analysis of past decades of research. European Management Journal, 37:6, 694-707.

KINGSMAN, B., HENDRY, L., MERCER, A. \& SOUZA, A. D. 1996. Responding to customer enquiries in make-to-order companies. Production, 6:2, 195-207.

KORTMANN, S., GELHARD, C., ZIMMERMANN, C. \& PILLER, F. T. 2014. Linking strategic flexibility and operational efficiency: The mediating role of ambidextrous operational capabilities. Journal of Operations Management, 32:7, 475-490.

LIN, H.-F., SU, J.-Q. \& HIGGINS, A. 2016. How dynamic capabilities affect adoption of management innovations. Journal of Business Research, 69:2, 862-876.

LUBATKIN, M. H., SIMSEK, Z., LING, Y. \& VEIGA, J. F. 2006. Ambidexterity and performance in smallto medium-sized firms: The pivotal role of top management team behavioral integration. Journal of management, 32:5, 646-672.

LUGER, J., RAISCH, S. \& SCHIMMER, M. 2018. Dynamic balancing of exploration and exploitation: The contingent benefits of ambidexterity. Organization Science, 29:3, 449-470.

LYNN, M. R. 1986. Determination and quantification of content validity. Nursing research.

MACDUFFIE, J. P. 1995. Human resource bundles and manufacturing performance: Organizational logic and flexible production systems in the world auto industry. Industrial \& labor relations review, 48:2, 197-221.

MARCH, J. G. 1991. Exploration and exploitation in organizational learning. Organization science, 2:1, 71-87.

MATTHEWS, R. L., TAN, K. H. \& MARZEC, P. E. 2015. Organisational ambidexterity within process improvement. Journal of Manufacturing Technology Management, 26:4, 458-476.

MIRON-SPEKTOR, E., INGRAM, A., KELLER, J., SMITH, W. \& LEWIS, M. 2017. Microfoundations of organizational paradox: The problem is how we think about the problem. Academy of Management Journal, amj. 2016.0594.

MUDA, M. S. \& HENDRY, L. 2003. The SHEN model for MTO SMEs - A performance improvement tool. International Journal of Operations \& Production Management, 23:5-6, 470-486.

NETLAND, T. H. \& FRICK, J. 2017. Trends in manufacturing strategies: A longitudinal investigation of the International Manufacturing Strategy Survey. International Manufacturing Strategy in a Time of Great Flux. Springer.

O'REILLY, C. A. \& TUSHMAN, M. L. 2013. Organizational ambidexterity: Past, present, and future. The Academy of Management Perspectives, 27:4, 324-338.

O'REILLY, C. A. \& TUSHMAN, M. L. 2008. Ambidexterity as a dynamic capability: Resolving the innovator's dilemma. Research in organizational behavior, 28, 185-206.

OECD \& COMMUNITIES, S. O. O. T. E. 2005. Oslo Manual.

PENG, D. X. \& LAI, F. 2012. Using partial least squares in operations management research: A practical guideline and summary of past research. Journal of Operations Management, 30:6, 467-480. 
PERTUSA-ORTEGA, E. M. \& MOLINA-AZORÍN, J. F. 2018. A joint analysis of determinants and performance consequences of ambidexterity. BRQ Business Research Quarterly, 21:2, 84-98.

PETRONI, A., ZAMMORI, F. \& MAROLLA, G. 2017. World class manufacturing in make-to-order batchproduction SMEs: an exploratory analysis in northern Italy. International Journal of Business Excellence, 11:2, 241-275.

PISANO, G. P. 2017. Toward a prescriptive theory of dynamic capabilities: connecting strategic choice, learning, and competition. Industrial and Corporate Change, 26:5, 747-762.

PODSAKOFF, P. M. \& ORGAN, D. W. 1986. Self-reports in organizational research: Problems and prospects. Journal of management, 12:4, 531-544.

POLIT, D. F. \& BECK, C. T. 2006. The content validity index: are you sure you know what's being reported? Critique and recommendations. Research in nursing \& health, 29:5, 489-497.

PRAJOGO, D. I. \& SOHAL, A. S. 2003. The relationship between TQM practices, quality performance, and innovation performance: An empirical examination. International Journal of Quality \& Reliability Management, 20:8, 901-918.

PROTOGEROU, A., CALOGHIROU, Y. \& LIOUKAS, S. 2011. Dynamic capabilities and their indirect impact on firm performance. Industrial and Corporate Change, 21:3, 615-647.

RINGLE, C. M., SARSTEDT, M. \& STRAUB, D. 2012. A critical look at the use of PLS-SEM in MIS Quarterly. MIS Quarterly (MISQ), 36:1.

RUCKER, D. D., PREACHER, K. J., TORMALA, Z. L. \& PETTY, R. E. 2011. Mediation analysis in social psychology: Current practices and new recommendations. Social and Personality Psychology Compass, 5:6, 359-371.

SALVADOR, F. \& FORZA, C. 2004. Configuring products to address the customization-responsiveness squeeze: A survey of management issues and opportunities. International journal of production economics, 91:3, 273-291.

SCHILKE, O. 2014. Second-order dynamic capabilities: How do they matter? Academy of Management Perspectives, 28:4, 368-380.

SCHRIBER, S. \& LÖWSTEDT, J. 2020. Reconsidering ordinary and dynamic capabilities in strategic change. European Management Journal, 38:3, 377-387.

STEVENSON, M., HENDRY, L. C. \& KINGSMAN, B. 2005. A review of production planning and control: the applicability of key concepts to the make-to-order industry. International journal of production research, 43:5, 869-898.

STEVENSON, M. \& VANHARANTA, M. 2015. The effects of managerial decision making behaviour and order book size on workload control system implementation in Make-To-Order companies. Production Planning \& Control, 26:2, 97-115.

SWINK, M., NARASIMHAN, R. \& KIM, S. W. 2005. Manufacturing practices and strategy integration: effects on cost efficiency, flexibility, and market-based performance. Decision Sciences, 36:3, 427-457.

TAMAYO-TORRES, J., TAMAYO-TORRES, J., ROEHRICH, J. K., ROEHRICH, J. K., LEWIS, M. A. \& LEWIS, M. A. 2017. Ambidexterity, performance and environmental dynamism. International Journal of Operations \& Production Management, 37:3, 282-299.

TEECE, D. J. 2007. Explicating dynamic capabilities: the nature and microfoundations of (sustainable) enterprise performance. Strategic management journal, 28:13, 1319-1350.

TEECE, D. J. 2017. A capability theory of the firm: an economics and (strategic) management perspective. New Zealand Economic Papers, 53:1, 1-43.

THURER, M., STEVENSON, M., SILVA, C., LAND, M. J. \& FREDENDALL, L. D. 2012. Workload Control and Order Release: A Lean Solution for Make-to-Order Companies. Production and Operations Management, 21:5, 939-953.

ÚBEDA-GARCÍA, M., CLAVER-CORTÉS, E., MARCO-LAJARA, B., ZARAGOZA-SÁEZ, P. \& GARCÍA-LILLO, F. 2018. High performance work system and performance. Journal of Business Research, 88, 397-406. 
VOSS, C. A. 1995. Alternative paradigms for manufacturing strategy. International Journal of Operations \& Production Management, 15:4, 5-16.

WALECZEK, P., VON DEN DRIESCH, T., FLATTEN, T. C. \& BRETTEL, M. 2019. On the dynamic bundles behind operations management and research and development. European Management Journal, 37:2, 175-187.

WILDEN, R., DEVINNEY, T. M. \& DOWLING, G. R. 2016. The architecture of dynamic capability research identifying the building blocks of a configurational approach. The Academy of Management Annals, 10:1, 997-1076.

WINTER, S. G. 2003. Understanding dynamic capabilities. Strategic management journal, 24:10, $991-$ 995.

WOLF, C. \& FLOYD, S. W. 2017. Strategic planning research: Toward a theory-driven agenda. Journal of Management, 43:6, 1754-1788.

WU, J., WOOD, G., CHEN, X., MEYER, M. \& LIU, Z. 2020. Strategic ambidexterity and innovation in Chinese multinational vs. indigenous firms: The role of managerial capability. International Business Review, 29:6, 101652.

ZAMANZADEH, V., GHAHRAMANIAN, A., RASSOULI, M., ABBASZADEH, A., ALAVI-MAJD, H. \& NIKANFAR, A.-R. 2015. Design and implementation content validity study: development of an instrument for measuring patient-centered communication. Journal of caring sciences, $4: 2,165$.

ZENNARO, I., FINCO, S., BATTINI, D. \& PERSONA, A. 2019. Big size highly customised product manufacturing systems: a literature review and future research agenda. International Journal of Production Research, 57:15-16, 5362-5385.

ZHAO, X., LYNCH JR, J. G. \& CHEN, Q. 2010. Reconsidering Baron and Kenny: Myths and truths about mediation analysis. Journal of consumer research, 37:2, 197-206.

ZIMMERMANN, A. \& BIRKINSHAW, J. 2016. Reconciling capabilities and ambidexterity theories. The Oxford Handbook of Dynamic Capabilities. Oxford University Press.

ZORZINI, M., HENDRY, L., STEVENSON, M. \& POZZETTI, A. 2008. Customer enquiry management and product customization: An empirical multi-case study analysis in the Italian capital goods sector. International Journal of Operations \& Production Management, 28:12, 1186-1218. 